\title{
Doubts voiced in Japan over controversial AIDS legislation
}

Tokyo

JAPAN's proposed AIDS (acquired immune deficiency syndrome) prevention law is coming under a barrage of criticism from doctors, lawyers and haemophiliacs.

The AIDS bill, due to be debated in the current session of the Diet, was hurriedly drafted by the Ministry of Health and Welfare earlier this year during a blaze of publicity surrounding the death of Japan's first female AIDS patient. But the proposed legislation was immediately condemned as "inhumane" by the National Association of Haemophiliacs (see Nature 326, 232; 1987), and the Japan Society of Blood Transfusion also opposed the law on the grounds that it would drive potential carriers underground. Now lawyer and doctors have joined the chorus of criticisms.

The most contentious provisions in the proposed legislation are that: doctors must report the age, sex and source of infection of AIDS-virus carriers to the prefectural government concerned within seven days and, if a doctor judges that a patient could ignore his instructions, he must report the patient to the prefectural authorities; prefectural governors are authorized to question and recommend or order AIDS tests and medical check-ups for people infected with AIDS or suspected of being infected; those who fail to keep the secrets of patients will be imprisoned or fined.

The Japan Civil Liberties Union, an Saturday declared its opposition to the legislation because it may violate the human rights and freedom of patients and also because, in the union's view, public health specialists were not adequately consulted in the rush to draft the law - an opinion supported by a society of doctors association of lawyers and law scholars, on

concerned with public health

This week, the Japanese Society for Hygiene will send an appeal to the Ministry of Health and Welfare listing three major defects in the law: (1) the law was drafted very hurriedly without sufficient consultation, and without adequate explanation of intent; (2) the major purpose of the law is to identify the population of carriers, but the law may very well scare away at-risk groups, leaving haemophiliacs as the most visible potential carriers and exposing them to social discrimination; and (3) although the law includes punishment against violation of privacy, very few cases of violation of privacy of individuals have ever been prosecuted.

Evidence is already mounting to support the society's view. Doctors report a decrease of about 20 per cent in the number of haemophiliacs visiting AIDS clinics since news of the law broke. And, according to Yukio Yasuda, of the National Association of Haemophiliacs, a Japanese child infected with AIDS has been refused admission to pre-school, and other school required a pupil suffering from haemophilia to bring a certificate stating that he was not infected with AIDS.

Professor Gen Ohi of Teikyo University, who drafted the hygiene society's appeal, contrasts Japan's reaction to AIDS with that of the United Kingdom and the United States, where there are far more AIDS cases. Mr Kenneth Clarke, UK Minister of Health, rejected notification of AIDS in 1985, and at a meeting at the US Center's for Disease Control in February participants almost unaminously rejected mandatory testing. Instead of the present AIDS legislation, Ohi advocates setting up open-door clinics, where patients can receive treatment and tests in complete confidence. David Swinbanks

\section{Reagan seeks expert advice on AIDS}

\section{Washington}

President Ronald Reagan has announced a national commission to advise him on ways of dealing with the spread of AIDS. But commission members, yet to be announced, are not going to find it easy to reconcile the rapidly diverging views on public information about AIDS and AIDS testing.

The commission "will review research, assess the long-term impact on the healthcare system, and recommend ways to protect those who do not have the disease". On the last topic, the administration appears deeply split between those, like Education Secretary William Bennett, who favour compulsory testing and stress on morality in education, and those, like the Surgeon General C. Everett Koop, who favour expublic education on the use of condoms (see Nature 327,3 ; 1987).

Backing for Koop's view comes this week in a new report from the Public Health Service's Centers for Disease Control (CDC). The report has not yet been made public but, according to CDC researchers, it argues that compulsory testing would be a use of resources that could not be justified by the current pattern of spread of the AIDS virus. Instead it recommends a major programme to encourage high-risk groups to come forward voluntarily for testing. panding voluntary test programmes and

\section{Telescope opens \\ London}

THE £20-million, 15-m-diameter joint venture James Clerk Maxwell sub-millimetre telescope, opened by the Duke of Edinburgh on the top of the $4,000-m$ Mauna Kea in Hawaii on 27 April, will start its observing career over-subscribed $\mathbf{6 . 5}$ times. The Royal Observatory, Edin-

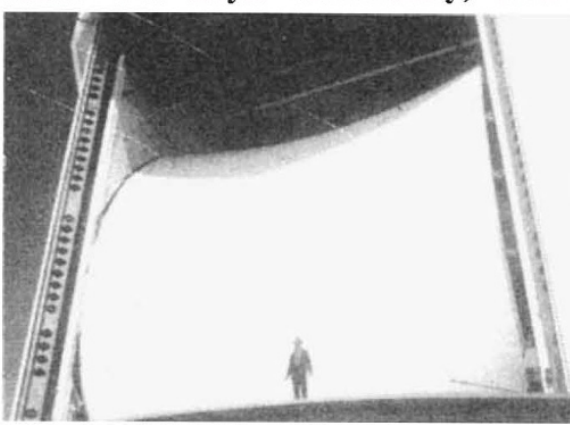

burgh, which is looking after the programme, received 85 proposals of which it could only choose 15 for the first sixmonth observing period beginning in July. Optimum running time will be 16 hours a day, unless further money can be found for more extended operation. Theoretically, the telescope could work round the clock as the protective membrane (shown above - with its designer) effectively cuts out all solar radiation.

Angela Croome

\section{WHO derides vaccine scare}

\section{London}

REPORTS of a link between the successful global smallpox eradication programme and the emergence of AIDS have been dismissed by the World Health Organisation (WHO). Dr Jonathan Mann, director of the WHO AIDS programme, said that allegations that the smallpox vaccine, vaccinia, may have activated HIV infections "join many other unproven and speculative ideas about the origin of AIDS". Mann is anxious that unfounded speculation could jeopardize other vaccination programmes, and called for work that links smallpox vaccine with AIDS to be submitted for scientific scrutiny.

It was emphasized at the 40 th $\mathrm{WHO}$ assembly meeting this week in Geneva that the world should concentrate on action to prevent the spread of AIDS, rather than speculating on its origins.

Kathy Johnston

The British aid organization War on Want says up to 75 million Africans could soon be affected by AIDS. Using figures from the WHO conference, the group predicts that the virus will spread along Africa's lines of transport to Zimbabwe, Mozambique and Angola, and that South Africa "may face a major and widespread epidemic in the near future." 